\title{
Turkey-Azerbaijan Economical and Political Relations
}

\author{
Elnur Hasan Mikail1, Yurdagül Atun², Ata Atun² \\ ${ }^{1}$ Department of International Relations, Faculty of Economics and Business Administration, Kars Kafkas University, \\ Kars, Turkey \\ ${ }^{2}$ Cyprus Science University, Girne, TRNC \\ Email: emikail@turansam.org, yurdagulatun@csu.edu.tr, ataatun@csu.edu.tr
}

How to cite this paper: Mikail, E. H., Atun, Y., \& Atun, A. (2019). Turkey-Azerbaijan Economical and Political Relations. Open Journal of Political Science, 9, 512-524. https://doi.org/10.4236/ojps.2019.93029

Received: May 16, 2019

Accepted: June 11, 2019

Published: June 14, 2019

Copyright (C) 2019 by author(s) and Scientific Research Publishing Inc. This work is licensed under the Creative Commons Attribution International License (CC BY 4.0).

http://creativecommons.org/licenses/by/4.0/

\begin{abstract}
This study investigates mainly economic, political and social relations between Azerbaijan and Turkey. The study covers the economic improvements in the period between 1990-2005. In the study, data relating to the general economic development after the independence of the Republic of Azerbaijan after 1990 are examined. Azerbaijan was one of the Republics of the former Soviet Union. After 1990 following the collapse of the Union of the Soviet Socialist Republics, the State of Azerbaijan declared its independence. As a newly independent State, Azerbaijan had a great potential for economic relations with Turkey. Even today, this is still the case. From education to tourism, from construction sector to trade, there are Turkish companies all over Azerbaijan. Azerbaijan is a member state of The Commonwealth of Independent States (CIS) emerged after the collapse of the Soviet Union and led by the Russian Federation. This makes it easier for Turkey to reach the CIS market via Azerbaijan, and provides a port to Europe for Azerbaijan via Turkey.
\end{abstract}

\section{Keywords}

Azerbaijan's Economy, Azerbaijan Republic, Economical Relations between Azerbaijan and Turkey, Newly Independent States (NIS), Turkish Economy, Political Relations between Azerbaijan and Turkey, Project of the Turkish Union

\section{Introduction}

Turkey became the first country to recognize the independence of Azerbaijan on November 9, 1991. Diplomatic relations between the two countries were estab- 
lished on 14 January 1992 (Aktukun, 1995).

Azerbaijan is an important country to Turkey that shared common language, culture and history (Aliyarov \& Mahmudov, 1989). Turkey, tried to establish close partnership relations with Azerbaijan from the beginning, and has been a strong supporter of its ability to overcome the challenges and several difficulties Azerbaijan faced in the course of developing as a new independent Republic. Turkey believes that the consolidation of Azerbaijan's independence, realization of the economic potential of natural resources from the Caspian Sea and protection of territorial integrity are necessary to be implemented (Gumilev, 1991).

Turkey-Azerbaijan relations based on the fundamental mutual respect for the sovereign equality of the both countries, continue to be developed in all areas such as political, economic, trade, education, transport, telecommunications, agriculture, social security, health, culture, science and tourism (Makas, 1990) and (http://www.mfa.gov.tr).

Numerous agreements have been signed to form the basis for the relations between the two countries. High-level contacts and visits at all levels are carried out regularly and frequently ${ }^{1}$ (Allahverdiyev \& Goycayli, 1996).

The Nagorno-Karabakh Problem, which emerged as a result of the occupation of Azerbaijan by Armenia, is the most important obstacle to political stability, economic development and regional cooperation in the South Caucasus (Minorsky, 1953) and (Hartill, 1990). The controversy has caused more than one million people in Azerbaijan to be displaced or to become immigrant in their own countries (Allahverdiyev \& Goycayli, 1996).

Turkey is actively participating in the efforts of Minsk Group trying to find a peaceful solution the the Nagorno-Karabakh issue in the framework of OSCE. Turkey considers the Minsk Process as an important mechanism that may contribute to a just, peaceful and lasting solution to Karabakh conflict (Yildirim \& Ozonder, 1991) and (Gumilev, 1990). However, the conflict has still not been resolved. The Minsk Group needs to be more active, direct and creative in order to fulfill its duty to resolve the conflict peacefully (Abbasli, 2001).

Turkey supports the idea that direct and indirect negotiations being conducted between Armenia and Azerbaijan would be helpful in finding a peaceful solution to the problems in the process (Hartill, 1990). Turkey is ready to support a solution to the Nagorno Karabakh problem that would be acceptable to both sides of the conflict (Yildirim \& Ozonder, 1991). Turkey, also believes in the necessity of creation of new ways to overcome the impasse in the settlement process and especially contribution of the international community in a more active manner in the peace process in order to meet the expectations of more than one million escapee (Aras, 1998).

In this context, a forum for dialogue between the Ministers of Foreign Affairs of Turkey, Azerbaijan and Armenia is established with Turkey's initiative in order to act as "facilitator" in the settlement of the Karabakh problem and to ex${ }^{1}$ ARAS (1998), Orhan; Azerbaycan Davamız, Hamle Yayınları, İstanbul, s. 45-68. 
change views on other regional issues (Hartill, 1990). The first meeting was held on 15 May 2002 in Reykjavik. The second meeting of the Ministers of Foreign Affairs was held on June 28, 2004 at the NATO Istanbul Summit margin. Parties emphasized that this trilateral meeting of the three countries can be a useful tool for the process of normalization of relations between the three countries and settlement of the Karabakh conflict and they think that effective contribution of Turkey can accelerate the solution of regional problems (Aras, 2003).

On the other hand, Turkey continues to carry out bilateral contacts with the parties within the scope of the Karabakh conflict ${ }^{2}$ (Bunyadov, 1989).

In the first 3 months of 1997, Azerbaijan's foreign trade with Turkey has been around $\$ 45$ million ( $\$ 38$ million import, export $\$ 7$ million). In the same period of 1996, the total foreign trade volume was $\$ 53$ million (imports $\$ 44$ million, exports $\$ 9$ million). The biggest reason for the decline in foreign trade between the two countries is the high tax rates in customs. Food items take the first place.in products exported by Turkey to Azerbaijan. Our exported products are; flour and bakery products, pharmaceutical products, margarine, wheat, olive oil, sunflower oil, milk and milk products, eggs, pasta, beer, potatoes, cube and granulated sugar, chocolate and confectionery products, fruit juices, cheese, biscuits, prepared leather products, synthetic detergents, soaps, wallpapers, sanitary ware materials, machinery for the textile industry, articles made of rubber and plastic, white goods, telecommunication products, electrical energy, and so on (Aras, 2003).

The main commodities we import from Azerbaijan include raw aluminum, cotton, polyethylene, raw leather, cotton yarn, wool, raw copper, alcoholic beverages and phosphate fertilizers. Apart from this, we can say that the informal foreign trade transactions between the two countries, especially the suitcase trade, are larger. Several protocols and agreements were signed on various dates for the development of bilateral economic and commercial relations with Azerbaijan. These include the "Agreement on Reciprocal Promotion and Protection of Investments" and "Agreement on the Avoidance of Double Taxation Between Turkey and Azerbaijan" which are considered the most important by our investors. The first of these agreements was put into effect as of 31 July 1996 and the other from 1 January 1998. The contribution of Turkish capital to Azerbaijan, which is in the transition period and in need of investment, is significant ${ }^{3}$ (Bunyadov, 1989).

\section{Turkey-Azerbaijan Economical and Political Relations}

Turkey was the second largest import market of Azerbaijan in 2000. 11\% of the total imports and $6 \%$ of the total exports were realized with Turkey. In parallel with the developing political and economic relations since 1991, our volume of

${ }^{2}$ http://www.mfa.gov.tr/default.en.mfa; Son Güncelleme: 22.10.2004; Bilgiler T. C. Dışişleri Bakanlığı Web Sitesi'ndenalınmıştır.

${ }^{3}$ T. C.; BAŞBAKANLIK; TÜRK İŞBİRLİĞİ VE KALKINMA İDARESİ BAŞKANLIĞI; AZERBAYCAN CUMHURIYETİ; https://www.tika.gov.tr/tr, 20 Aralık, 2004. 
foreign trade and its surplus is increasing favorably for our country (Allahverdiyev \& Goycayli, 1996).

However, with the effect of the devaluation of the Ruble after the Russian crisis in 1998, Russian goods provided an absolute price advantage in the Azerbaijani market and because of the low level of income of the people, the price became the most important criterion for determining the demand (Swietochowski, 1988). As a result of these developments, demand for goods from our country has decreased. This situation directly affected our businessmen doing business in Azerbaijan (Resulzade, 1990).

In 1999, our trade with Azerbaijan decreased compared to previous years. In the years 1996, 1997 and 1998 Turkey was the largest good import market of Azerbaijan, while Turkey ranked the second after Russia in the years 1999 and 2000. One of the most important factors in the decrease of our exports is that the contracting works undertaken by our contractor companies have been completed to a large extent and new major projects have not started. In 2001 and 2002, exports started to increase again (Swietochowski, 1988).

Foreign Trade with Turkey in the years 1992-2000 (million $\$)^{4}$ (http://www.treasury.gov.tr).

\begin{tabular}{lccccccc} 
& 1996 & 1997 & 1998 & 1999 & 2000 & 2001 & 2002 \\
Import: & 216.8 & 179.7 & 220.1 & 142.4 & 128.4 & 148.1 & 156.1 \\
Export: & 39.7 & 41.3 & 135.8 & 69.0 & 104.9 & 67.3 & 83.3 \\
Balance: & -177.1 & -138.4 & -84.3 & -73.4 & -23.5 & -80.785 & -72 \\
\multicolumn{7}{l}{ Major Goods Imported from Azerbaijan: }
\end{tabular}

Major goods imported from Azerbaijan are diesel fuel, cotton, crude oil, polyethylene, leather, alcoholic beverages, crude aluminum, benzene (Aras, 2003).

\section{Major goods we export to Azerbaijan:}

Wheat flour, pharmaceutical products, synthetic detergents, electric energy, passenger cars, accumulators, car tires, furniture, building materials, wallpapers, sanitary ware materials, machinery and equipment for textile industry, leather garments, cosmetics, knitting products, rubber and articles made of plastic, television, refrigerator etc., glass containers, aluminum profile, articles of ordinary metal, machines for the manufacture of wood, telecommunication equipment, cables, electrical materials, stationery, ready-made garments, margarine, wheat, olive oil, sunflower oil, butter, soybean oil, machinery and equipment for food industry, tea, canned, paste, ice cream, vegetables (potatoes and onions), eggs and chicken meat, mineral water, soft drinks, beer, pasta, cube and granulated sugar, chocolate and candy products, juices, cheese, biscuits

(http://www.economy.gov.az).

\section{Turkish Investors in Azerbaijan:}

Azerbaijan is a country preferred by Turkish businessmen in terms of investment and commercial activities with many advantages. In this respect, many Turkish companies have established a joint enterprise in Azerbaijan, opened ${ }^{4}$ Kaynak: T. C. DTM-Bakü T. Müş. 1999, 2000 yıllarıraporları, Azerbaycan Devletİstatistik Komitesiyayınları. 
branches or representative offices (http://www.treasury.gov.tr).

Number and Distribution according to status of Turkish Companies in Azerbaijan: ${ }^{5}$ (http://www.economy.gov.az).

$\begin{array}{llllllll}\text { Status } & 1991-1995 & 1996 & 1997 & 1998 & 1999 & 2000 & \text { Total } \\ \text { Partnership } & 394 & 72 & 78 & 67 & 33 & 16 & 660 \\ \text { \%100 Turkish Capital } & 176 & 65 & 116 & 126 & 42 & 36 & 561 \\ \text { Representations } & 29 & 8 & 21 & 23 & 17 & 8 & 106 \\ \text { TOTAL } & 599 & 145 & 215 & 216 & 92 & 60 & 1.327\end{array}$

Most of the Turkish firms operating in different fields prefer to trade or make small and medium sized investments. Areas of activity of these firms; oil, telecommunication, banking and insurance, food goods manufacturing, education, press-publishing, textile and apparel, transportation, automotive, forest products, iron and steel, non-ferrous metals, construction materials and contracting services (http://www.economy.gov.az).

Turkish companies play an important role in the transition of Azerbaijan to free market economy, directly and indirectly. As of the end of 2000, approximately 1327 Turkish companies, 100\% Turkish capital, joint enterprise, branch or representative office, acquired legal entity by carrying out official establishment procedures in Azerbaijan. A significant portion of these companies cannot continue their activities presently. There are currently around 600 Turkish companies operating in various sectors in Azerbaijan. The amount of investments made by the Turkish companies in Azerbaijan is estimated to be around $\$ 1.5$ billion and about 30,000 people are employed (Minorsky, 1953).

Turkey ranks the first country in the non-oil foreign investment in Azerbaijan. In order to operate the reserves owned by Azerbaijan, TPAO (Turkish Petroleum Corporation) is the partner in four of the twenty international consortia (Azeri-Çırak-Güneşli field, 6.75\%, Shah Sea Field 9\%, Kürdaş Field 5\% and Araz-Alov-Şark Field 10\%). Offshore. In addition, the joint institutions established by the two private Turkish companies (PET Holding and AtillaDogan Construction Ltd.) with the State Oil Company of Azerbaijan (SOCAR) are producing oil on land (Mishovdag and HilliBabazanan sites). The total commitment of more than 50 Turkish contracting firms of various sizes in Azerbaijan is approximately 650 million Dollars. Baku International Airport and A.C. Most of the important prestige buildings such as the Central Bank building were successfully completed and delivered by Turkish contractors. About 3000 people are employed in this sector and $70 \%$ of them are Azerbaijani citizens. There are 5 banks and 3 insurance companies with Turkish capital operating in the banking sector (http://www.bbc.com).

US $\$ 91.7$ million portion of the US $\$ 250$ million loan from Turk Eximbank to Azarbaijan Republic has been used. In addition to the US $\$ 100$ million loan for financing the export, the Bank received USD 150 million of project loans fir funding the electrical home appliances plant, bakery ovens and airport renova- 
tion were funded. A total of USD 74.8 million Debt Delay Agreement was signed on 08.08.1996 due to the repayment problems. As per the signed intergovernmental protocol, USD 48.7 million was converted into government debt, and as the repayment problems still continue, efforts to reschedule the balance of 29.3 US dollars continue. In addition, a 19.63 million-dollar loan was made available and extended to Nakhichevan by Turk Eximbank (http://www.economy.gov.az).

Turkey was the first country to recognize the Republic of Azerbaijan which gained its independence in 1991 (Ulku, 2000). The strengthening of political independence is only possible with the strengthening of economic independence. Therefore, Turkey has offered its economic resources, international finance and free market economy experience to Azerbaijan's benefit. For this purpose, the first Turkey-Azerbaijan agreement on the development of economic and trade relations was signed on 01.11.1992. As a result of this agreement, the contacts and visits of Turkish businessmen with Azerbaijan were initiated, and fairs and similar activities were encouraged and cooperation was made in many branches of the industry such as transportation and communication, construction and oil exploration. As in other areas Turkey has mobilized their facilities to the benefit of Azerbaijan in this field for widely and quickly development of economic relations between the two countries (Allahverdiyev \& Goycayli, 1996).

In the course of the time starting from the establishment of diplomatic relations with Azerbaijan till the beginning of the year 1997, a total of 1.000 firms were established in various status such as; jointly by Turkish companies 520,400 branches and an independent companies and representations of 50 companies. Approximately 600 of them are active presently. The fields of activity of these companies include petroleum, telecommunications, banking and insurance, education, media, construction and construction materials, transportation, food, textile and apparel, transportation, automotive, forest products, iron and steel and non-ferrous metals. The amount of capital brought to Azerbaijan by 1000 Turkish companies established or located in Azerbaijan in any form of cooperation whatsoever has reached to the amount of \$1 billion as of the end of 1996 . The number of Azerbaijani companies operating in Turkey is 41 and the level of capital is $\$ 18$ million (http://www.economy.gov.az).

The Turkish companies in business in Azerbaijan such asDogan Petrol Company, Pet Holding, Efes Industrial Investment, Netas, Teletas, Turkcell, Bay Holding, DHT Construction, Ram Foreign Trade, Rumeli Holding, Tekfen, Etsun, TC Ziraat Bank, AnadoluSigorta make great contributions to meet the needs of the Azerbaijani people in important sectors such as construction, communication, oil, transportation, banking and food. As for foreign trade, Turkey has exported to Azerbaijan a total of $\$ 681.1$ million US \$worth of goods: 102.7 million US \$in 1992, 68.2 million US \$in 1993, 132.1 million US \$in 1994, 161.3 million US \$in 1995 and 216.8 million US \$in 1996. On the other hand, in the last five years, Turkish companies have made a total amount of 139.2 million US \$worth of import from Azerbaijan. Despite the significant increase in Turkey's exports to Azerbaijan, imports from Azerbaijan has not increased consi- 
derably. Therefore, the establishment of the foreign trade balance between the two countries is a very important issue. In the year 1996, Turkey was ranking the first country in the import of Azerbaijan with a total value of 216 million \$. Compared to the previous years, compared to the previous years, foreign trade in Azerbaijan increased by $35 \%$ - $45 \%$. About one-quarter ( $\$ 216.8$ million) worth of import good is provided from Turkey and 39.7 million US \$foreign currency inflow was provided by means of export to Turkey which constitutes the $15.7 \%$ of annual export ( $\$ 961$ million) Azerbaijan (Aras, 1998).

As is known, the common language, history and culture of unity between Azerbaijan and Turkey is an important factor in further expansion of our economic relations (Aliyarov \& Mahmudov, 1989). As a matter of fact, the number of foreign trades, number of investment companies and investment amounts that have started after the independence of the Republic of Azerbaijan has continuously increased every year (Ulku, 2000).

To date, several agreements and protocols have been signed in the economic and commercial area, including the agreement on the mutual promotion and protection of investments between the two countries and the agreement on the prevention of double taxation. However, the volume of foreign trade and investments today is below the real potential of both countries. For this reason, the Republic of Azerbaijan has to increase the rules of banking, customs legislation, trade law, foreign trade procedures and legal rules to international levels (Abbasli, 2001).

Azerbaijan is a country with a bright and shining future in 2000s with its underground and aboveground riches, qualified and cheap labor and its determination to move to free market economy. Opportunities for mutually beneficial business cooperation of Turkey and the Turkish businessmen in the reconstruction and economic development of Azerbaijan is increasing every day. As a matter of fact, in the last two years in Azerbaijan, inflation has been withdrawn and important steps have been taken in the field of economic stability. The growing interest of Japanese business circles in Azerbaijan is the best proof of this. One of the most important developments of the last year is that serious Turkish companies have been expanding and intending to expand their activities in the fields of oil, telecommunications, construction, banking and insurance, metallurgy, textile and medium-sized industrial enterprises in Azerbaijan ${ }^{6}$ (Zeynaloglu, 1992).

Azerbaijan's legal arrangements giving an end to implementation of the Export Tax on the products to be exported from the beginning of 1997, enacting numerous new regulations to complete the legal infrastructure for the transition to the liberal economy, determination of the annual and long-term programs for the priority areas of the country and determination of the annual and long-term programs, privatization and regulating foreigners' joint ventures and affiliates will significantly increase the cooperation between our countries

(http://www.treasury.gov.tr).

In the first 3 months of 1997, Azerbaijan's foreign trade with Turkey has been ${ }^{6} \mathrm{http} / / /$ www.foreigntrade.gov.tr/DUNYA/RAPOR/baku/tureko.htm; 12 Mayıs, 2005. 
around $\$ 45$ million ( $\$ 38$ million import, export $\$ 7$ million). In the same period of 1996, the total foreign trade volume was $\$ 53$ million (imports $\$ 44$ million, exports $\$ 9$ million). The biggest reason for the decline in foreign trade between the two countries is the high tax rates in customs ${ }^{7}$.

Food ingredients and products takes the first place in exports to Azerbaijan from Turkey. Our exported products are; flour and bakery products, pharmaceutical products, margarine, wheat, olive oil, sunflower oil, milk and milk products, eggs, pasta, beer, potatoes, cubes and granulated sugar, chocolate and confectionery products, fruit juices, cheese, biscuits, prepared leather products, synthetic detergents, soap, wallpapers, sanitary ware materials, machinery for the textile industry, articles made of rubber and plastic, white goods, telecommunication products, electrical energy, and so on (http://www.economy.gov.az).

The main commodities we import from Azerbaijan include raw aluminum, cotton, polyethylene, raw leather, cotton yarn, wool, raw copper, alcoholic beverages and phosphate fertilizers. Apart from this, we can say that the informal foreign trade transactions between the two countries, especially the suitcase trade, are larger (http://www.bbc.com).

Among the companies operating in Azerbaijan, the Turkish firms are the biggest both in terms of number of companies and sector diversity. Since 1991, Turkish companies have come to Azerbaijan to invest in oil, construction, telecommunications, banking, insurance, transportation, transportation, buying and selling food products, textile, furniture, decoration, press-publishing and printing, sale of construction materials, garment, bakery products, production of various services, financial and legal consultancy, machinery manufacturing, stationery, forest products, tea packaging, battery manufacturing, metal processing, etc. ${ }^{8}$ (http://www.mfa.gov.tr).

As of the end of April 1997, 400 100\% foreign capital companies, 520 joint enterprises and 50 representative offices were officially established and registered in Azerbaijan. The number of independent firms, joint institutions and representative offices currently operating is around 550 and others are not active. As of April 1997, the total amount of foreign capital that Turkish firms have put in Azerbaijan is around $\$ 1$ billion. The reason why official figures appear less than the actual figure is that there are firms that operate without establishing any companies, and that companies show low capital to avoid paying more taxes and duties. The most important reason for not having invested more in Azerbaijan with rich underground and surface resources, skilled work force and very close to our country and having advantage of language is the lack of legal infrastructure and legal regulations ${ }^{9}$ (Gumilev, 1990).

As is known, first meeting of the Turkey-Azerbaijan Joint Economic Commission (JEC) was held in Ankara between 25-26 February 1997. As reflected in 
the meeting protocol, the parties has reached a consensus on the commercial relations (general situation, trade committee, fairs and exhibitions, establishment of business centers in Baku, Eximbank loans, wheat transportation, banking), energy cooperation, oil pipeline, oil and natural gas exploration activities within the framework of cooperation in the field of industry, electrical energy, mining, contracting, free zones; land, air and rail transport, telecommunication, education, environment, health, etc.(http://www.treasury.gov.tr).

Between 25-27 March 1997 under the chairmanship of the Minister of State Ayfer Yılmaz joint seminars and bilateral talks were organized by the Aegean Exporters' Union organization on the topic of “Turkey-Azerbaijan Investment and Cooperation Opportunities in Baku". The seminar, participated by more than 120 businessmen from Azerbaijan and Turkey has contributed significantly to the exchange of views between the businessmen on the development of economic, trade and cultural cooperation opportunities between the two countries (Makas, 1990).

The official visit of the President of the Republic of Azerbaijan Heydar Aliyev between 5-9 May 1997 to Turkey has created wide repercussions in both countries, within the framework of the further development of friendship and cooperation opportunities between the countries and has paved the way for important step to be taken (Ulku, 1996). Between 14-18 May 1997 TURKISH EXPO 97 BAKU; TURKISH TRADE AND INDUSTRY PRODUCTS FAIR" was organized by Forum Fairs and Development Inc. for the second time in Baku. Ambassador of Turkey to Baku Mr. O. Faruk LOĞOĞLU, Prime Minister of the Republic of Azerbaijan Artur RESIZZADE, Minister of Foreign Economic Relations Kudret GULIYEV and the representatives of the Chamber of Commerce and Industry, as well as numerous Azerbaijani authorities, Azerbaijani and Turkish businessmen and press members participated in the opening of the fair. A total of 92 companies and organizations participated in "TURKISH EXPO 97" Fair. Foodstuffs (flour, oil, eggs, pasta, nuts, tea), cleaning products, automobile spare parts, furniture, apparel, communication products, stationery, building materials, agricultural machinery, sanitary ware materials, shoes and numerous other products were exhibited during the fair (Eyuboglu, 1993).

Turkey supports direct and indirect negotiations being conducted between Armenia and Azerbaijan expecting that these negotiations would be helpful in finding a peaceful solution to the problems (Hartill, 1990). Turkey is ready to support a solution on the Nagorno Karabakh problem that would be acceptable to both sides (Yildirim \& Ozonder, 1991). Furthermore, Turkey believes that it is necessary to create new ways to overcome the impasse in the settlement process and to provide contribution of the international community in a more active manner in the peace process in order to meet the expectations of more than one million escapee. In this context, a forum for dialogue between the Ministers of Foreign Affairs of Turkey, Azerbaijan and Armenia was established with Turkey's initiative to act as a "facilitator" for the settlement of the Karabakh prob- 
lem and on other regional issues. The first meeting was held on 15 May 2002 in Reykjavik (Gumilev, 1990).

The second meeting of the Ministers of Foreign Affairs was held on June 28, 2004 at the NATO Istanbul Summit margin. Parties emphasized that this trilateral meeting of the three countries can be a useful tool in the process of normalization of relations and settlement of the Karabakh conflict and effective contribution of Turkey to the can accelerate the solution of regional problems (Yildirim \& Ozonder, 1991). On the other hand, Turkey, continues bilateral contacts with the parties within the scope of the Karabakh conflict

(http://www.mfa.gov.tr).

Several protocols and agreements were signed on various dates for the development of bilateral economic and commercial relations with Azerbaijan. These include "Agreement on Reciprocal Promotion and Protection of Investments" and "Between Turkey and Azerbaijan Agreement on the Avoidance of Double Taxation" are considered the most important by our investors. The first of these agreements was put into effect as of 31 July 1996 and the other from 1 January 1998. The contribution of Turkish capital to Azerbaijan, which is in the transition period and in need of investment, is significant (Ari, 1999).

Turkey ranks the second biggest import market for Azerbaijan. 11\% of the total imports and $6 \%$ of the total exports were realized with Turkey in the year 2000. In parallel with the developing political and economic relations since 1991, our increasing volume of foreign trade is giving a surplus in favor of our country. However, with the effect of the devaluation of the Ruble after the Russian crisis in 1998, Russian goods provided an absolute price advantage in the Azerbaijani market and because of the low level of income of the people, the price became the most important criterion for determining the demand. As a result of these developments, demand for goods from our country has decreased. This situation directly affected our businessmen doing business in Azerbaijan. As a result of these developments, demand for goods from our country has decreased. This situation directly affected our businessmen doing business in Azerbaijan. In 1999, our trade with Azerbaijan decreased compared to previous years. While most imports were made from Turkey in the years 1996, 1997 and 1998, Turkey ranks second after Russia in the years 1999 and 2000 (Swietochowski, 1988).

One of the most important factors in the decrease of our exports is that the contracting works undertaken by our contractor companies have been completed to a large extent and new major projects have not started. In 2001 and 2002, exports started to increase again (Ismayilov, 1992).

Major goods Turkey imports from Azerbaijan are diesel fuel, cotton, crude oil, polyethylene, leather, alcoholic beverages, crude aluminum and gasoline (Aktukun, 1995).

Major goods Turkey exports to Azerbaijan are wheat flour, pharmaceutical products, synthetic detergents, electric energy, passenger cars, accumulators, car tires, furniture, building materials, wallpapers, sanitary ware materials, machinery and equipment for textile industry, leather garments, cosmetics, knitting 
products, rubber and articles made of plastic, television, refrigerator etc., glass containers, aluminum profile, articles of ordinary metal, machines for the manufacture of wood, telecommunication equipment, cables, electrical materials, stationery, ready-made garments, margarine, wheat, olive oil, sunflower oil, butter, soybean oil, machinery and equipment for food industry, tea, canned, paste, ice cream, vegetables (potatoes and onions), eggs and chicken meat, mineral water, soft drinks, beer, pasta, cube and granulated sugar, chocolate and candy products, juices, cheese, biscuits (Ismayilov, 1992).

Azerbaijan is a country preferred by Turkish businessmen in terms of investment and commercial activities with many advantages. In this respect, many Turkish companies have established a joint enterprise in Azerbaijan, opened branches or representative offices (http://www.bbc.com).

Number and distribution according to status of Turkish Companies in Azerbaijan.

\begin{tabular}{cccccccc}
\hline Status & $1991-1995$ & 1996 & 1997 & 1998 & 1999 & 2000 & Total \\
\hline $\begin{array}{c}\text { Partnership } \\
\text { 100\% Turkish }\end{array}$ & 394 & 72 & 78 & 67 & 33 & 16 & 660 \\
Capital Company & 176 & 65 & 116 & 126 & 42 & 36 & 561 \\
$\begin{array}{c}\text { Representations } \\
\text { TOTAL }\end{array}$ & 29 & 8 & 21 & 23 & 17 & 8 & 106 \\
& 599 & 145 & 215 & 216 & 92 & 60 & 1.327
\end{tabular}

Most of the Turkish firms operating in different fields prefer to trade or to make small and medium sized investments. Areas of activity of these firms are oil, telecommunication, banking and insurance, food goods manufacturing, education, press-publishing, textile and apparel, transportation, automotive, forest products, iron and steel, non-ferrous metals, construction materials and contracting services and so on (http://www.treasury.gov.tr).

\section{Conclusion}

Turkish companies play an important role in the transition of Azerbaijan to free market economy, directly and indirectly based on their experience. As of the end of 2000, approximately 1327 Turkish companies, 100\% Turkish capital, joint enterprise, branch or representative office, have acquired legal entity by carrying out official establishment operations in Azerbaijan. A significant portion of these companies cannot continue their activities. There are currently around 600 Turkish companies operating in various sectors in Azerbaijan. The amount of investments made by Turkish companies in Azerbaijan is estimated to be around $\$ 1.5$ billion and about 30,000 people are employed (Ari, 1999).

Turkey ranks the first country in the non-oil foreign investment in Azerbaijan. In order to operate the reserves owned by Azerbaijan, TPAO (Turkish Petroleum Corporation) is the partner in four of the twenty international consortia (Azeri-Çırak-Güneşli field, 6.75\%, Shah Sea Field 9\%, Kürdaş Field 5\% and Araz-Alov-Şark Field 10\%). Offshore (http://www.mfa.gov.tr). In addition, the 
joint institutions established by the two private Turkish companies (PET Holding and Atilla Dogan Construction Ltd.) with the State Oil Company of Azerbaijan (SOCAR) are producing oil on land (Mishovdag and HilliBabazanan sites) (http://www.economy.gov.az).

The total commitment of more than 50 Turkish contracting firms of various sizes in Azerbaijan is approximately 650 million Dollars. Many prestigious projects such as Baku International Airport and A.R. Central Bank building were successfully completed and delivered. About 3000 people are employed in this sector and 70\% of them are Azerbaijani citizens (http://www.mfa.gov.tr). There are 5 banks and 3 insurance companies with Turkish capital operating in the banking sector. There is a difference between Azerbaijan and Turkey about 2+ hours. Air temperatures are in parallel with Turkey. It is between -15 and 5 degrees in winter and $25-35$ degrees in summer. Azerbaijan service passport and private passport holder Turkish citizens do not need visa to enter Azerbaijan. Tourist passport holders are required to have a visa (Aras, 1998).

\section{Conflicts of Interest}

The authors declare no conflicts of interest regarding the publication of this paper.

\section{References}

Abbasli, N. (2001). The Liberation Struggle in Azerbaijan. Istanbul: Balina Publications.

Aktukun, I. (1995). How the CIS Was Reached from the USSR. Determinations for a Marxist Analysis. Istanbul: Sorun Publications.

Aliyarov, S., \& Mahmudov, Y. (1989). Sources for the History of Azerbaijan History. Baku: Azerbaijan University Publications.

Allahverdiyev, N., \& Goycayli, S. (1996). Economic and Political Geography of Azerbaijan Republic. Baku: Azerbaijan Teacher Publications.

Aras, O. (1998). Our Azerbaijan Case. Istanbul: Hamle Publications.

Aras, T. R. (2003). Foreign Politics of Ataturk. Istanbul: Kaynak Publications.

Ari, T. (1999). International Relations and Foreign Politics (3rd ed.). Istanbul: Alfa Publications.

Bunyadov, Z. (1989). Azerbaijan in VII-IX Centuries. Baku: Azerbaijan State Publications.

Eyuboglu, Z. I. (1993). History of Sufism, Cults and Sects and Sects in All Aspects. Istanbul: Der Publications.

Gumilev, L. N. (1990). Ethnic Geography Conception in Historical Process. Sankt Peterburg: Nauka Publications.

Gumilev, L. N. (1991). Analysis of the Thousand Year Process around the Caspian Sea. Baku: Azerbaijan State Publications.

Hartill, L. R. (1990). Azerbaijan Events of 1918-1922 in the Memoirs of an Armenian (Translated by SipahiCataltepe). Istanbul: Kastas Publications.

Ismayilov, M. (1992). Azerbaijan History. Baku: Azerbaijan State Publications.

Makas, Z. A. (1990). Azerbaijan History and Cultural Geography. Ankara: Kok Social and 
Strategic Researches, Kok Publications.

Minorsky, V. (1953). Studies in Caucasian History. With a Map. London: Taylor's Foreign Press.

Resulzade, M. E. (1990). Foundation of Azerbaijan Republic and Present Situation. Entire Works: 1. Prepared by Dr. Yavuz Akpinar, Irfan Murat Yildirim, Sabahattin Cagin. Istanbul: Meryamer Publications.

Swietochowski, T. (1988). From Muslim Community to National Identity Russian Azerbaijan 1905-1920. Istanbul: Baglam Publications.

Ulku, I. (1996). From the Red Star to Crescent: Stormy Life of Haydar Aliyev (2nd ed.). Istanbul: Kamer Publications.

Ulku, I. (2000). Azerbaijan, after Independence. Istanbul: Dogan Books Publications.

Yildirim, D., \& Ozonder, C. (1991). Karabakh File (2nd ed.). Ankara: Turkish Culture Research Institute Publications.

Zeynaloglu, C. (1992). Extended Azerbaijan History. Baku: Azerbaycan State Bookstore Publications.

http://www.bbc.com

http://www.economy.gov.az

http://www.mfa.gov.tr

http://www.treasury.gov.tr 